\title{
Retorika Dakwah Ustadz Evie Effendi di Video Youtube
}

\author{
Regi Raisa Rahman ${ }^{1 *}$, Atjep Mukhlis ${ }^{1}$, Acep Aripudin ${ }^{2}$ \\ 1Jurusan Komunikasi dan Penyiaran Islam. UIN Sunan Gunung Djati Bandung \\ 2Prodi Komunikasi dan Penyiaran Islam, Pascasarjana UIN Sunan Gunung Djati Bandung \\ *Email: regirabman96@gmail.com
}

\begin{abstract}
ABSTRAK
Pesatnya perkembangan teknologi media sosial membuat kepopuleran mudah didapat. Evie Effendi merupakan salah satu da'i populer di media sosial Youtube dilihat dari banyaknya jamaah, kalangan muda khususnya. Ia da'i nyentrik dan mempunyai ciri khas dalam dakwahnya yaitu mengenakan pakaian modis kaum muda serta selalu menambahkan humor dalam ceramahnya. Tujuan penelitian ini yaitu untuk mengetahui, menganalisis dan mengkontruksi proses penyusunan retorika dalam dakwah Evie Effendi di video Youtube. Penelitian ini menggunakan beberapa teori seperti, teori retorika yang diungkapkan oleh Aristoteles tentang seni untuk mempengaruhi orang lain (the art of persusasion) menggunakan prinsip ethos, pathos dan logos. Teori retorika Jalaludin Rakhmat tentang imbauan persuasi dalam berpidato. Metode yang digunakan dalam penelitian ini adalah metode kualitatif dengan pendekatan deskriptif. Data yang diperoleh melalui observasi, dokumentasi dan sampling. Data-data dianalisis dan dideskripsikan sesuai dengan teori-teori terkait. Hasil penelitian membuktikan bahwa retorika yang diterapkan oleh Evie Effendi meliputi ethos, pathos, dan logos, serta lima imbauan persuasi. Gaya bahasa yang digunakan Evie Effendi dalam dakwahnya meliputi, ta'lim dan tarbiyah (pengajaran dan pendidikan), tazkir dan tanbih (pengingat dan penyegaran kembali), targhib dan tabsyir (penggemaran amal sholeh dan penampilan berita pahala), tarbib dan inzar (menakut-nakuti dan menyampaikan berita siksa), qashash dan riwayat (penampilan kisah atau cerita masa lalu), serta amar dan nabi (perintah dan larangan). Kemudian, humor yang digunakan adalah humor exaggeration, parodi, burlesque, dan belokan mendadak.
\end{abstract}

Kata Kunci : Retorika; Evie Effendi; Dakwah; Youtube

\section{ABSTRACT}

The rapid development of social media technology has made it easy to get popularity. Evie Effendi is one of the popular da'i on Youtube social media seen from the many worshipers, especially young people. He was quirky and had a characteristic in bis preaching which was 
R.R.Rahman, A. Mukhlis, \& A.Aripudin

wearing fashionable clothes for young people and always adding bumor in bis lectures. The purpose of this study is to find out, analyze and construct the process of preparing rhetoric in the preaching of Evie Effendi on Youtube videos. This study uses several theories such as the rhetorical theory expressed by Aristotle about art to influence others (the art of persuasion) using the principles of ethos, pathos, and logos. The rhetorical theory of Jalaluddin Rakhmat about the appeal of persuasion in speeches. The method used in this study is a qualitative method with a descriptive approach. Data obtained through observation, documentation, and sampling. The data are analyzed and described in accordance with related theories. The results of the study prove that the rhetoric applied by Evie Effendi includes ethos, pathos, and logos, and five persuasion calls. The language style used by Evie Effendi in her preaching included, ta'lim and tarbiyah (teaching and education), tazkir and tanbih (reminders and refreshes), targhib and tabsyir (good charity and news reward appearance), tarbib and inzar (scare and news torture display), qashash and history (Appearance of stories or stories of the past), and amar and nabi (orders and probibitions). Then, the bumor used is humor exaggeration, parody, burlesque, and sudden turns.

Keywords : Rhetoric; Evie Effendi; Da'wah; Youtube

\section{PENDAHULUAN}

Belakangan muncul suatu fenomena baru dalam dakwah yaitu da'i selebritis atau da'i populer yang sangat digandrungi oleh masyarakat, terutama kaula muda. Fenomena ini tidak terlepas dari pengaruh era modern yang ditandai dengan berkembangnya ilmu pengetahuan dan teknologi. Media massa menjadi tidak hanya sebatas televisi dan surat kabar, tetapi berkembang melahirkan media baru yaitu internet yang sekarang ini menjadi paling banyak diakses oleh masyarakat. (Amnestika, 2014).

Hampir semua media menayangkan ceramah, renungan dan tausiyah dari para da'i. Sebagian da'i memang muka lama, tetapi sebagian lagi adalah da'i muka baru. Da'i yang terakhir inilah dengan tidak menunggu lama, popularitas bagai selebritis melekat padanya karena sering tampil di media. Mereka tampil dengan gaya dan ciri khas masing-masing, entah asli dari bawaanya atau hanya skenario manajemen untuk menaikkan rating.

Seorang da'i mampu melantunkan ayat Alqur'an dengan indah, petuahpetuahnya yang bijak, piawai dalam menyampaikan materi dakwah dan mempunyai kharisma tinggi seolah-olah disimbolkan dengan da'i tradisional (Hidayatullah, 2015). Penulis tidak hendak mengatakan bahwa da'i selebriti atau da'i populer ini tidak memiliki kemampuan tradisional. Tetapi, dapat dilihat perbedaan keduanya.

Perbedaan tersebut terletak pada pengalaman apa yang sudah didakwahkan. Da'i tradisional akan muncul bila materi dakwah yang mereka sampaikan berbanding lurus dengan pengamalan yang ditunjukan dalam praktik keseharian mereka, sementara da'i selebriti atau da'i populer (da'i pop) tidak 
banyak dituntut untuk menyeimbangkan keduanya dalam mendapatkan kharismanya.

Salah satu da'i dapat dikategorikan pop adalah Evie Effendi. Evie Effendi sering mengisi acara di beberapa stasiun televisi dan di media sosial internet, seperti instagram, youtube, dan facebook sehingga membuatnya populer di masyarakat. Untuk menjadi da’i terkenal/populer, Evie Effendi telah melalui perjalanan panjang. Sebelum Evie Effendi populer, ia pernah menjadi berandal, adu jotos, hingga dipenjara selama 3 bulan pada tahun 2000. Belajar dari kejadian-kejadian itu, ia berhijrah menjadi pribadi yang "taat beragama" dan rajin mendatangi kajian atau pengajian di masjid-masjid. Ia belajar lebih dekat memahami ilmu pengetahuan dan syariat ajaran Islam. Semasa itu, Evie Effendi mulai berani menularkan pengetahuan agama Islam kepada teman-temannya, secara bertahap ia mengajarkan baca Alqur'an dan mengajak sahabatnya untuk hijrah (Gandapura. 2017). Inilah awal Evie Effendi melakukan dakwah hingga sekarang

Pemahaman itu juga yang terus digali oleh Evie Effendi selama ia dalam proses hijrah hingga dakwahnya berkembang sampai sekarang. Ia memiliki tekad untuk mengajak seluruh kaula muda di Bandung khususnya, berhijrah seperti dirinya. Tekadnya tersebut direalisasikan dalam bentuk dakwah yang unik dan nyentrik. Ia tidak berpakaian layaknya da'i-da'i populer yang lain, berbaju koko atau gamis, tetapi ia justru berpakaian modis dan gaul, layaknya kaula muda yang menjadi objek dakwahnya. Ia juga merangkul para pelaku kejahatan, korban narkoba dan pentolan geng motor. Banyak di antara mereka yang hijrah ke jalan yang lebih baik dikarenakan dakwah Evie Effendi.

Dalam menghadapi tantangan era modern seorang da'i harus memiliki kemampuan komunikasi yang baik, menurut Jalaludin Rakhmat (1985: 262) ada enam komponen kredibilitas komunikan yaitu pertama, expertise, yaitu mempunyai keahlian dalam suatu topik yang dibicarakan. Kedua, trust worthnness, yaitu dapat dipercaya karena cerdas, mampu dan berakhlak mulia, dan berpengalaman. Ketiga, communication skill, yaitu kemampuan dalam berkomunikasi. Keempat, knowledge, yaitu pengetahuannya haruslah luas. Kelima, attitude, yaitu baik dalam bersikap. Keenam, social and culture system, yaitu mampu beradaptasi dengan sistem dan budaya sosial.

Menurut Basrah Lubis (1991: 57) pendakwah harus memahami antara memberikan ceramah di lingkungan sosial kelas bawah dengan masyarakat berpendidikan. Seorang da'i dituntut untuk memiliki kepandaian retorika, sebab dengan penguasaan retorika seorang da'i dapat memotivasi pendengar menuju tingkah laku atau sikap yang sesuai dengan pesan dakwahnya.

Retorika atau sering disebut public speaking adalah suatu bentuk komunikasi 
lisan yang disampaikan kepada orang banyak, tetapi retorika itu tidak hanya sekedar berbicara dihadapan umum, melainkan merupakan suatu gabungan antara seni berbicara dan pengetahuan suatu masalah tertentu untuk meyakinkan pihak orang banyak melalui pendekatan persuasif (Rahmat, 1999: 9). Rasulullah dalam berdakwah selalu mengedepankan kehati-hatian, supaya pesan yang akan beliau sampaikan dapat diterima dengan baik dan jelas, sebagaimana hadits Rasulullah SAW: "Berbicaralah kepada manusia, menurut kadar akal (kecerdasan) mereka masing-masing. (HR. Muslim)" (Fachrudin Hs, etc., 1978: 346).

Sesuai penjelasan di atas yang menjadi hal penting dari keberhasilan dakwah Evie Effendi adalah kemampuannya dalam menyampaikan pesan dakwah, sehingga banyak jamaahnya yang berhijrah dari yang buruk berpindah kejalan yang lebih baik terutama dari kalangan kaula muda. Keberhasilannya tersebut tidak lepas dari pemanfaatan media lain seperti media sosial Youtube. Evie Effendi memiliki channel Youtube sendiri yang bernama Evie Effendi Official dengan jumlah pengikut 184 ribu orang dan 225 video. Dengan adanya media sosial ini tentu masyarakat diuntungkan dapat dengan mudah mengakses video ceramah Evie Effendi tanpa batasan ruang dan waktu (Amnestika, 2014).

Penelitian terdahulu yang membahas retorika adalah Retorika Dakwah Ustadzah Haneen Akira di Video Youtube yang disusun oleh Aishatul Cholifah pada tahun 2018. Penelitian ini membahas mengenai retorika Ustadzah Haneen Akira di video youtube. Dalam mengidentifikasi persoalan tersebut secara mendalam dan menyeluruh, dalam penelitian ini digunakan metode kualitatif non kancah. Kemudian data yang diperoleh, peneliti menggunakan observasi dan dokumentasi. Data kemudian dianalisis menggunakan analisis semiotik Ferdinan De Saussure.

Perbedaan dengan penelitian saat ini yaitu terdapat pada teknik analisis data. Pada teknik analisi data ini, tahapan pertama yang akan penulis lakukan adalah dengan mentranskripkan rekaman audio visual atau video dari ceramah Evie Effendi yang didapatkan dari Youtube, kedalam bentuk tulisan atau teks agar mudah untuk dianalisis. Kemudian, penulis akan mendeskripsikan dan menganalisis retorika yang digunakan oleh Evie Effendi berdasarkan teori-teori yang ada.

\section{LANDASAN TEORITIS}

Penggunaan Retorika dalam dakwah, baik sebagai strategi maupun seni yang bertujuan agar dakwah (ceramah) lebih baik dan indah. Retorika (seni dalam berbicara) merupakan kebutuhan dasar kemanusiaan. Retorika dalam dakwah biasanya diterapkan agar pelaksanaan dakwah (ceramah) lebih menarik, lebih indah dan menghindari suasana monoton atau datar.

Retorika sebagai seni berbicara makin intensif digunakan para penceramah atau mubaligh ketika menyampaikan ceramahnya atau tablighnya. Nama-nama 
da'i mulai paling senior hingga yang junior seperti Zaenudin MZ, Jujun Junaedi dan Evie Effendi diantara da'i-da'i populer pada level nasional, lokal bahkan global menjadikan retorika sebagai strategi dalam menyusun kata dan kalimat dalam ceramahnya. Karenanya, seni berbicara (retorika) dalam berbicara didepan khalayak umat maupun diruangan akan tetap memberikan daya tarik karena merupakan salah satu kebutuhan dasar manusia.

\section{Kajian Teoritis}

\section{Teori Aristoteles}

Aristoteles mengasumsikan bahwa reotrika merupakan seni berbicara untuk mempengaruhi orang lain (Onong, 2013 :55). Aristoteles adalah seorang murid Plato yang paling cerdas. Tiga jilid buku telah ia tulis dengan judul De Arte Rhetorica. Dari Aristoteles, kita memperoleh lima tahap penyusunan pidato, yang terkenal sebagai The Five Canons of Rhetoric(Lima Hukum Retorika), sebagai berikut:

Pertama, Inventio (penemuan). Maksud dari penemuan disini, yaitu pembicara melakukan riset atau penggalian topik kepada khalayak dengan tujuan untuk mengetahui metode persuasi yang paling tepat. Pada tahap ini juga, komunikator menentukan tujuan dan mengumpulkan bahan yang sesuai dengan kebutuan khalayak (Rakhmat, 2011: 7).

Kedua, Dispotitio (penyusunan). Penyusunan disini maksudnya ialah pembicara harus mengorganisasikan pesan atau Aristoteles menyebutnya taxsis atau pembagian (Rahmat, 2011: 7). Pembagian tersebut ia susun menjadi tiga bagian yaitu: pendahuluan, badan, dan kesimpulan (Onong ,2013 :55). Menurutnya, pendahuluan dapat dijadikan sebagai upaya untuk menarik perhatian khalayak, menumbuhkan kredibilitas, dan menjelaskan tujuan.

Ketiga, Elucatio (gaya). Pada tahap ini pembicara menggunakan bahasa yang tepat dalam menyampaikan pesannya. Aristoteles mengatakan "pilihlah bahasa yang sesuai, benar, dan dapat diterima; pilih kata-kata yang jelas dan langsung; sampaikan kalimat yang indah, mulia, dan hidup; dan sesuaikan bahasa dengan pesan, khalayak, dan pembicara" (Rakhmat, 2011: 8).

Keempat, Memoria (memori). Pada tahap ini pembicara harus mengingat apa yang akan disampaikannya dengan mengatur materi atau pesan. Diantara semua peninggalan retorika klasik, memori menjadi hal yang kurang mendapatkan perhatian

Kelima, Pronuntiatio (penyampaian). Penyampaian disini maksudnya adalah pembicara harus pandai menyampaikan pesannya dengan cara yang tidak monoton. Pembicara harus pandai dalam mengatur kata-kata, olah vocal, dan gestur tubuhnya (Ridwan, 2013: 52-53).

Kemudian, Aristoteles menyebutkan ada tiga cara untuk mempengaruhi manusia yaitu: Ethos, adalah suatu sikap yang menunjukkan seorang komunikator 
memang ahli dibidangnya atau memiliki kredibilitas, sehingga meyakinkan khalayak untuk mempercayainya (Uchjana, 1993: 352). Komunikator harus sanggup menunjukkan kepada khalayak bahwa ia memiliki pengetahuan yang luas, kepribadian yang terpercaya, dan status yang terhormat (Rakhmat, 2011: 7). Pathos, berarti pembicara melibatkan perasaan atau emosi. Seorang komunikator harus mampu membangkitkan perasaan khalayaknya. Ini biasanya ditandai dengan seorang komunikator menggunakan bahasa atau kata-kata yang dapat menggugah perasaan atau emosi khalayak (Uchjana, 1993: 352). Jalaludin Rakhmat mengemukakan bawa komunikator harus menyentuh hati khalayak: perasaan, emosi, harapan, kebencian dan kasih saying mereka. Para ahli retorika modern menyebutnya imbauan emosional (emotional appeals). (Rakhmat, 2011: 7). Logos, pembicara meyakinkan khalayak dengan mengajukan bukti atau yang kelihatan sebagai bukti. Disini pembicara mendekati khalayak lewat otaknya. (Rakhmat, 2011: 7).

\section{Teori Jalaludin Rakhmat}

Menurut Jalaludin Rakhmat (2013: 294), komunikator harus menyentuh motif khalayak dalam mempengaruhi orang ketika berpidato, agar mereka dapat mengaplikasikan pesan-pesan yang disampaikan. Jalaludin Rakhmat mengasumsikan bahwa prinsip-prinsip menyampaikan pidato perlu dimiliki seorang komunikator, salah satunya yaitu penggunaan bentuk persuasi yang meliputi, berikut:

Pertama, Imbauan rasional adalah pendekatan terhadap khalayak melalui akal mereka disertai dengan bukti empirik agar mereka yakin terhadap bukti tersebut dan dapat mencernanya dengan baik.

Kedua, Imbauan emosional adalah imbauan melalui perasaan senang, haru, dan semangat khalayak. Biasanya ketika komunikator menggunakan imbauan ini, dapat ditandai dengan perkataan dan gaya bahasa yang menyentuh hati.

Ketiga, Imbauan takut adalah imbauan yang digunakan untuk membuat perasaan orang lain menjadi cemas, khawatir, bahkan mengancam serta dapat membangkitkan perasaan emosi.

Keempat, Imbauan ganjaran adalah imbauan dengan memberikan khalayak kesempatan untuk mendapatkan pahala atau imbalan dengan membuat suatu perjanjian.

Kelima, Imbauan motivasional adalah imbauan yang digunakan untuk menyentuh kondisi internal khalayak, dan imbauan ini diklasifikasikan ke dalam dua motif yaitu motif biologis dan psikologis.

\section{Kajian Konseptual}


Sejak dahulu, dakwah telah mengalami perubahan dan perkembangan. Jika dahulu dakwah dilakukan dengan sederhana, saat ini dakwah dilakukan dengan berbagai metode, media, dan strategi. Seiring dengan kemajuan teknologi di zaman modern ini, dakwah dikemas dengan berbagai alat dan media komunikasi yang canggih. Oleh karena itu, aktivitas dan materi dakwah tersebar di berbagai media, seperti televisi, radio, surat kabar, dan internet. Metode dakwah pada zaman dahulu salah satunya yaitu metode ceramah. Metode ini adalah salah satu karakteristik dakwah pada masa nabi dalam periode Mekah. Meskipun demikian, saat ini metode ceramah diragukan keefektifitasannya oleh para pengkritik. Mereka menyatakan bahwa dakwah dengan metode ceramah sudah terlalu konvensional. (Abidin, 2013: 123).

Walaupun metode ceramah ini mendapat banyak kritikan, ternyata metode ini tidak dapat tergantikan oleh metode lain yang lebih canggih (Abidin, 2013: 123). Metode ceramah memiliki keunikan tersendiri, yaitu dapat secara langsung face to face, lebih akrab dan lebih personal. Apalagi dalam Islam, ceramah tidak bisa dihindari dari beberapa aktifitas ibadah seperti, sholat jum'at, sholat Idul Fitri, sholat Idul Adha, dsb.

Menurut Yusuf Zainal Abidin (2013: 124), dalam ilmu komunikasi, ceramah atau pidato merupakan bagian dari Public speaking. Public speaking merupakan komunikasi yang melibatkan pembicara dan khalayak yang banyak, sehingga dibutuhkan keahlian khusus dalam melakukannya.

Dalam buku Retorika Modern karya Jalaludin Rakhmat, terdapat beberapa tahap dalam mempersiapkan dan menyusun pidato, yaitu:

\section{Memilih Topik dan Tujuan}

Sebelum berpidato, pembicara harus mengetahui apa yang akan disampaikan kepada khalayak dan apa yang dibutuhkan oleh khalayak. Singkatnya, pembicara harus menyiapkan topik bahasan dan tujuan. Menurut Jalaludin Rakhmat (2011: 19) terdapat beberapa cara dalam merumuskan topik dan memperjelas tujuan, yaitu:

Pertama, sumber-sumber topik. Prof Wayne N. Thompson menyusun sistematika sumber topik sebagai berikut: pengalaman pribadi, hobi dan keterampilan, pengalaman pekerjaan atau profesi, pelajaran sekolah atau kuliah, pendapat pribadi, peristiwa hangat dan pembicaraan publik, masalah pribadi, kilasan biografi, kejadian khusus, dan minat khalayak. Sesuai dengan sumber topik yang dipaparkan diatas, pembicara dapat menentukan topik sesuai dengan latarbelakang pengetahuannya. (Rakhmat, 2011: 20).

Kedua, merumuskan judul. Jalaludin Rakhmat (2010: 23) merumuskan judul dengan tiga syarat berikut, yaitu: Pertama, judul harus relevan, artinya judul harus sesuai dengan topik yang akan disampaikan. Kedua, judul harus profokatif, yaitu harus menimbulkan minat pendengar untuk mengetahui isi pidato. Ketiga, judul harus singkat, artinya judul harus mudah dipahami dan diingat oleh pendengar. 
R.R.Rahman, A. Mukhlis, \& A.Aripudin

Ketiga, menentukan tujuan. Menurut Jalaludin Rakhmat (2010: 24) tujuan terbagi menjadi dua macam, yaitu tujuan umum dan tujuan khusus. Tujuan umum dirumuskan menjadi tiga hal: Pertama, tujuan bersifat informatif yaitu untuk memberitahukan dan menambah pengetahuan pendengar. Kedua, tujuan bersifat persuasif, yaitu untuk mempengaruhi pendengar agar percaya terhadap sesuatu serta membakar semangat dan antusiasmenya. Ketiga, tujuan bersifat rekreatif, yaitu untuk menghibur pendengar.

Sementara itu, tujuan khusus adalah tujuan hasil dari penjabaran dari tujuan umum. Misalnya, dalam tujuan informative maka pembicara akan memaparkan informasi-informasi ilmiah mengenai suatu hal yang terjadi di masyarakat. Apa yang ingin dicapai oleh pembicara akan terlihat pada tujuan khususnya. (Rakhmat, 2011: 24).

\section{Mengembangkan Bahasan}

Apabila pembicara telah menentukan topik bahasan, maka selanjutnya pembicara perlu menentukan keterangan penunjang topik bahasan. Hal itu perlu dilakukan agar uraian menjadi jelas, menambah daya tarik dan mempermudah pengertian. Ada beberapa uraian yang dijelaskan oleh Jalaludin Rakhmat mengenai keterangan penunjang, yaitu:

Pertama, penjelasan. Penjelasan merupakan suatu keterangan penunjang. Penjelasan akan diperlukan dalam pidato informatif, karena uraiannya merupakan penjelasan. Penjelasan dapat digambarkan dengan definisi atau alatalat visual. Misalnya komunikasi berasal dari "communis" yang artinya kebersamaan. Definisi seperti ini disebut definisi etimologis. Arti komunikasi sudah dijelaskan oleh banyak sarjana. Satu diantaranya dapat kita ambil. Ini adalah definisi ahli (definition by authority). Komunikasi dapat berarti hubungan antara pembaca dengan penulis, antara pembicara dan pendengar. Cara ini disebut definisi contoh (definition by exemplication). Bila kita menjelaskan komunikasi secara terinci, ruang lingkup dan bagian-bagiannya, kita membuat define uraian (definition by explication). Tetapi bila kita menekankan komunikasi bukan urusan angkutan antar kota, bukan sekedar kontak saja, dan bukan pula sekedar bicara, kita sedang menjelaskan dengan definisi periolakan (definition by negotiation) (Rakhmat, 2011:27).

Kedua, contoh. Untuk memudahkan pendengar dalam memahami gagasan pembicara, maka pemberian contoh sangat diperlukan. Contoh dapat berupa ilustrasi atau cerita yang terinci. Ada dua macam ilustrasi: hipotesis dan faktual. Ilustrasi hipotesis terjadi bila kita membayangkan sesuatu yang akan terjadi atau menceritakan perumpamaan dengan tokoh rekaan sebagai penjelas pernyataan sebelumnya. Ilustrasi faktual yaitu cerita yang terjadi dalam kehidupan seharihari, kisah orang-orang besar atau peristiwa aktual dalam surat kabar dan majalah dapat dipakai untuk memperjelas pidato. Ada juga jenis contoh yang tidak terinci 
Retorika Dakwah Ustadz Evie Effendi di Video Youtube

yaitupemisalan (specific instances). Pemisalan adalah ilustrasi faktual yang dipadatkan. Biasanya ini dibuat karena pertimbangan waktu dan banyak contoh (Rakhmat, 2011: 27).

Ketiga, analogi. Analogi ialah perbandingan antara dua hal atau lebih untuk menunjukkan persamaannya atau perbedannya. Ada dua macam analogi: harfiyah dan kiyasan. Analogi harfiyah (literal analogy) ialah perbandingan diantara objekobjek dari kelompok yang sama, karena adanya persamaan dalam beberapa aspek tertentu. Membandingkan antara manusia dan monyet secara biologis adalah contohnya. Banyak ahli pidato yang menggunakan analogi kiasan. Objek-objek yang diperbandingkan tidak termasuk kelompok yang sama (Rakhmat, 2011: 28).

Keempat, testimoni. Testimoni adalah pernyataan ahli yang dikutip untuk menunjang keterangan. Pernyataan itu dapat diambil dari pidato, karangan, artikel makalah, laporan dan sebagainya. Testimoni dapat digunakan untuk memperlengkap keterangan (Rakhmat, 2011: 29).

Kelima, statistik. Statistik adalah angka-angka yang digunakan untuk menunjukkan perbandingan kasus dalam jenis tertentu. statistik diambil untuk menimbulkan kesan yang kuat, memperjelas dan meyakinkan. Tetapi karena angka sebenarnya hal yang abstrak, statistik baru baik digunakan bila statistik itu dibuat kongkret atau tidak membosankan. Gunakan bilangan yang dibulatkan. Hubungkan dengan hal-hal yang dapat diketahui oleh khalayak. Tunjukan sumber statistik yang tertentu (Rakhmat, 2011: 29).

Keenam, perulangan. Sesuatu yang diulang-ulang dapat menimbulkan kesan yang kuat. Perulangan bukan hanya sekedar menyebut kembali kata-kata yang telah diucapkan, tetapi juga menyebutkan gagasan yang sama dengan kata-kata yang berbeda (Rakhmat, 2011: 30).

\section{Cara Membuka dan Menutup Pidato}

Bagian paling penting dalam pidato adalah pembukaan. Karenanya, akan hancur komposisi pidato apabila gagal dalam pembukaan. Tujuan utama pembukaan pidato ialah membangkitkan perhatian, memperjelas latar belakang pembiaraan dan menciptakan kesan yang baik mengenai komunikator (Rakhmat, 2011: 53).

Menurut Jalaludin Rakhmat (2011: 53), cara membuka pidato bergantung pada topik, tujuan, situasi, dan khalayak. Cara-cara berikut dapat dijadikan sebagai pedoman: langsung menyebutkan pokok persoalan, melukiskan latarbelakang masalah, menghubungkan dengan peristiwa mutakhir atau kejadian yang tengah menjadi pusat perhatian khalayak, menghubungkan dengan peritiwa yang sedang diperingati, menghubungkan dengan tempat komunikator berpidato, menghubungkan dengan suasana emosi yang tengah meliputi khalayak, menghubungkan dengan kejadian sejarah yang terjadi di masa lalu, menghubungkan dengan kepentingan vital pendengar, memberikan pujian pada khalayak atas prestasi mereka, memulai dengan pernyataan yang mengejutkan, mengajukan pertanyaan provokatif atau serentetan pertanyaan, menyatakan 
kutipan, menceritakan pengalaman pribadi, mengisahkan cerita faktual, fiktif atau situasi hipotesis, menyatakan teori atau prinsip-prinsip yang diakui kebenarannya, dan membuat humor.

Selanjutnya, yang perlu diketahui adalah cara menutup pidato. Menutup pidato harus membuat para pendengar fokus terhadap kesimpulan yang akan diberikan oleh pembicara. Karena itu penutup pidato harus dapat menjelaskan seluruh tujuan komposisi, memperkuat daya persuasi, mendorong pemikiran dan tindakan yang diharapkan, menciptakan klimaks dan menimbulkan kesan terakhir yang positif (Rakhmat, 2011: 59).

Ada dua macam penutup yang buruk: berhent tiba-tiba tanpa memberikan gambaran komposisi yang sempurna, atau berlarut-larut tanpa pengetahuan dimana harus berhenti. Untuk menghindari hal seperti ini, penutup pidato harus direncanakan sebelumnya lebih baik dihapal diluar kepala. Berikut ini adalah beberapa cara menutup pidato: menyimpulkan atau mengemukakan ikhtisar pembicaraan, menyatakan kembali gagasan utama dengan kalimat atau kata yang berbeda, mendorong khalayak untuk bertindak, mengakhiri dengan klimaks, mengatakan kutipan sajak, kitab suci, peribahasa, atau ucapan ahli, menceritakan contoh yang berupa ilustrasi dari tema pembicaraan, menerangkan maksud sebenarnya pribadi pembicara, memuji dan menghargai khalayak, dan membuat pernyataan yang humoris atau anekdot lucu (Rakhmat, 2011: 60).

\section{Gaya Bahasa}

Gaya bahasa yang lengkap dapat dipelajari dari buku-buku kesusastraan (Rakhmat, 2011: 51). Ada enam gaya bahasa yang dapat digunakan oleh da'i dalam retorika dakwah, yang dijelaskan oleh Hasjmy dalam buku Dustur Da'wah Menurut Al Qur'an, yaitu:

Pertama, ta'lim dan tarbiyah. Uslub dakwah dalam Alqur'an nadanya bermacam-macam, menyesuaikan waktu dan keadaan. Dakwah Alqur'aniyah lebih diutamakan dengan pengajaran dan Pendidikan. Sasaran pokok dakwah Alqur'aniyah yaitu aqidah dan syar'iyah atau iman dan amal sholeh (Wibisono, 1992: 9).

Dengan demikian telah jelas bahwa dakwah dengan menggunakan ta'lim dan tarbiyah sesuai dengan Alqur'an. Ta'lim dan tarbiyah dalam hal ini yaitu mengajarkan dan mendidik manusia agar benar-benar mempunyai aqidah yang shahih dan bermuamalah dalam segala bidang dengan berpedoman pada ajaran Alqur'an. Dalam gaya bahasa bentuk ini, ta'lim yang berarti pengajaran yaitu mengajar atau memberi pelajaran yang bersandar pada pengetahuan dan penyelidikan. Tarbiyah atau pendidikan yaitu mendidik manusia agar dengan pengetahuan dan penyelidikan yang telah diajarkan itu benar-benar menjadi sadar akan akidah dan syari'ah. Da'i bertugas untuk membuka pandangan audiens untuk melihat kebenaran dan memberi pengertian kepada orang jahil akan 
hakikat kebenaran, dan dengan mengembangkan segala jalan pengajaran dan pendidikan, agar kebenaran itu sampai kepada audiens (A. Hasjmy, 1974: 266267).

Kedua, tazkir dan tanbih. Setelah mengajar dan mendidik yang berlandaskan ilmu pengetahuan dan penyelidikan, agar pengetahuan yang telah didapatinya dapat diamalkan dan tidak dilupakan, maka harus diingat dan disadarkan kembali akan Pendidikan dan pengajaran yang telah diterimanya. Disinilah dawkah menurut uslub Alqur'an harus berdasarkan tazkir dan tanbih. (A. Hasjmy, 1974: 272).

Pengingatan dan penyegaran kembali hanya berguna bagi orang-orang yang beriman, artinya orang yang telah mendapatkan pengajaran dan Pendidikan tentang keimanan, hal itu tidak akan berguna sama sekali bagi mereka yang belum pernah menerima Pendidikan dan pengajaran tersebut (A. Hasjmy, 1974: 272). Seperti yang dijelaskan dalam Alqur'an: "Dan ingatlah, karena sesungguhnya peringatan kembali akan berguna bagi orang yang telah beriman" (Q.S Az-Zariyat: 55).

Ketiga, targhib dan tabsyir. Untuk orang yang celaka dan tidak dapat memanfaatkan pengingatan dan penyegaran kembali akan pengethauan yang telah dipelajarinya harus terus didakwahi dengan nada yang lain, dengan harapan hatinya akan terbuka untuk menerima kebenaran. Bahasa yang tepat digunakan untuk manusia yang celaka yaitu targhib dan tabsyir. Di dalam Alqur'an surat AlBaqarah ayat 25 telah dijelaskan mengenai hal tersebut:

"Dan sampaikanlah berita gembira kepada mereka yang beriman dan berbuat baik, bahwa bagi mereka disediakan surge-surga yang mengalir sungai didalamnya. Setiap mereka diberi rezeki buah-buahan dalam surgesurga itu, mereka mengatakan: "inilah yang pernah diberikan pada kami dahulu." Mereka diberi buah-buahan serupadan untuk mereka didalamnya ada istri-istri yang suci dan mereka kekal didalamnya."

Imam Ghazali mengemukakan lima contoh uslub dakwah dalam Alqur'an yang bernada targhib dan tabsyir yaitu: permintaan ketaatan, penuntutan berakhlak mulia, pengasuhan bertaqwa, pengemaran beriman dan beramal sholeh, pendorong agar tambah mentaati (A. Hasjmy, 1974: 278-281).

Keempat, tarhib dan inzar. Untuk orang celaka yang masih membangkang setelah menerima dakwah yang bernadakan targhib dan tabsyir, maka harus dilanjutkan dengan dakwah yang bernada tarhib dan inzar (menakut-nakuti dan menyampaikan berita dosa). Gaya bahasa ini berisikan tentang penakutan kepada mad'u dengan menampilkan berita siksa akibat perbuatan tercela dan perkataan dusta (A. Hasjmy, 1974: 282).

Muhammad Ghazali mengemukakan ada lima contoh gaya Bahasa tarhib dan inzar, yaitu: penyebutan nama allah, penampilan kemesuman, pengungkapan tentang bahaya, penegasan adanya bahaya segera, penyebutan peristiwa akhirat 
R.R.Rahman, A. Mukhlis, \& A.Aripudin

(A. Hasjmy, 1974: 283).

Kelima, qashash dan riwayat. Gaya Bahasa ini merupakan tindakan selanjutnya apabila setelah diperingati dengan tarhib dan inzar masih tetap tidak sadar. Qashash dan riwayat Yaitu cerita masa lalu yang dialami oleh manusia atau suatu kaum tentang akibat baik dan buruk yang telah dialami disebabkan oleh perbuatannya (A. Hasjmy, 1974: 288).

Keenam, amar dan nahi. Tindakan terakhri yaitu dengan menggunakan gaya Bahasa Amar dan nahyi (perintah dan larangan). Ini maksudnya adalah gaya bahasa yang mengandung peringatan untuk mewajibkan kepada umat muslim agar melakukan perbuatan yang baik dan meninggalkan perbuatan yang buruk. Dalam Alqur'an banyak terdapat ayat yang bernadakan amar dan nahyi. Jadi, sifat dakwahnya adalah gotong royong saling terkait satu sama lain antara anggota masyarakat Alqur'an bahkan sampai antar kelompok dalam masyarakat (A. Hasjmy, 1974: 292).

\section{Humor}

Humor merupakan salah satu metode rekreatif dalam berdakwah, karena dengan adanya humor dalam dakwah, pendengar/mad'u menjadi tidak merasa bosan dengan dakwah yang disampaikan. Boleh jadi ada orang yang menangis karena gembira, tetapi jarang sekali orang tertawa karena sedih.

Dalam buku Retorika Modern (Rakhmat, 2011: 126-134) terdapat dua teori humor yang sering digunakan bukan saja oleh para pelawak tetapi juga digunakan oleh filusuf.

1). Teori Superioritas dan Degradasi

Menurut Plato dan Aristoteles, kita akan tertawa apabila menyaksikan sesuatu yang janggal, keliru atau cacat. Sesuatu yang janggal tersebut adalah objek tertawa kita, sedangkan subjeknya adalah pembicara. Kita akan menertawakan sesuatu yang janggal karena kita tidak mempunyai sifat-sifat janggal itu. Sebagai subjek, pembicara memiliki kelebihan (superioritas), dan objek tertawa kita mempunyai sifat-sifat yang rendah/janggal.

Teori ini memiliki teknik tertentu dalam penggunaannya. Diantara teknikteknik tersebut adalah: Exaggeration: berarti melebihkan sesuatu secara tidak proporsional. Teknik ini digunakan untuk membongkar kejelekan sejelas-jelasnya dengan maksud mengoreksinya. Parodi: adalah sejenis komposisi dimana gaya suatu karya (seperti prosa, puisi atau prosa liris) yang serius ditiru dengan maksud melucu. Dalam pidato rekreatif, parodi dapat berupa peniruan suara dan gaya bicara seorang tokoh atau peniruan verbal terhadap karya sastra atau karyakarya tulis yang serius. Ironi: adalah menggunakan kata-kata untuk menyampaikan makna yang bertentangan dengan makna harfiahnya. Burlesque: adalah teknik membuat humor dengan memperlakukan hal-hal yang seenaknya secara serius atau sebaliknya. Perilaku aneh para tokoh: para tokoh sudah menarik dengan 
sendirinya, apalagi bila perilakunya aneh. Karena itu, lelucon mengenai orang besar sangat digemari orang. Perilaku orang aneh: perilaku orang aneh selalu dijadikan bumbu-bumbu humor. Tetapi penggunaanya dalam pidato rekreatif harus dilakukan sangat hati-hati. Bila kita agak ceroboh, kita bisa dihukum karena SARA.

\section{2). Teori Bisosiasi}

Teori ini dirumuskan oleh Arthur Koestler, tapi berasal dari filusuf-filusuf besar seperti Pascal, Kant, Spencer, Schopenhauer. Dalam teori ini disebutkan bahwa, humor timbul karena kita menemukan hal-hal yang tidak diduga, atau kalimat yang menimbulkan dua macam asosiasi. Yang pertama kita sebut teknik belokan mendadak, dan yang kedua yaitu asosiasi ganda (puns). Belokan mendadak: teknik ini menggunakan daya Tarik pendengar agar memperhatikan pembicaraan anda dengan serius, kemudian dari situ anda katakanlah sebaliknya. Puns: adalah teknik mempermainkan kata-kata yang mempunyai makna ganda.

\section{HASIL DAN PEMBAHASAN}

Evie Effendi merupakan seorang ustadz yang cukup terkenal dikalangan kaula muda. Tetapi beliau sekilas tak tampak seperti ustadz, gayanya nyentrik seperti gaya anak muda, memakai kupluk, dan gaya bicaranya gaul, nyunda. Dengan gayanya itu, ia lebih dapat diterima oleh kalangan remaja dan pemuda.

Kepopulerannya menjadi seorang pendakwah menuntun Evie untuk mengisi di berbagai acara. Pada akhir tahun 2015 ia mulai mengisi di salah satu stasiun TV yaitu Net TV biro Jabar dalam acara Risalah Hati sampai sekarang pun ia masih mengisi di Net Tv biro Jabar. Di akhir tahun yang sama juga Evie mengudara melalui ceramahnya di salah satu radio Bandung yaitu Radio Hits dalam acara Mutiara Pagi setiap pukul 05.00-06.00 WIB (Baban Gandapurnama, 2017).

Banyaknya kegiatan dakwah yang Evie lakukan tidak membuatnya menjadi orang yang takabur atau sombong beliau senantiasa menjadi orang yang humble kepada para jamaahnya setiap kali berdakwah. Selain itu beliau juga aktif di media sosial seperti Instagram dengan membuat konten-konten video atau pesan-pesan singkat tentang Islam yang sangat bermanfaat bagi jamaah atau orang yang membaca/melihatnya. Ciri khas beliau selain menggunakan gaya busana yang berbeda adalah jargon atau motto beliau dalam berdakwah yaitu "Jangan Lupa Bahagia" (Fatturohman, 2017). Jargon tersebut sering beliau ucapkan ketika akan berdakwah atau pesan dalam konten video di media sosial. Sehingga masyarakat atau jamaah mengenali beliau dengan jargon tesebut. Salah satu pesan Evie Effendi yang seperti pantun:

"Dakwah itu mengajak, bukan mengejek

Dakwah itu merangkul bukan memukul

Dakwah itu memberi solusi, bukan beraksi, apalagi berselfi 
R.R.Rahman, A. Mukhlis, \& A.Aripudin

Dakwah itu beraksi, bukan berdiam diri” (Faturrahman, 2017).

\section{Proses Penyusunan Retorika dalam Dakwah Evie Effendi di Video Youtube}

Retorika merupakan seni berbicara yang memiliki peran penting dalam kegiatan dakwah, salah stau bentuk dakwah yang memerlukan kemampuan retorika yang baik adalah tabligh. Tabligh adalah suatu kegiatan menyampaikan pesan-pesan dakwah dengan lisan, tulisan, dan media elektronik, sehingga retorika perlu diterapkan oleh para mubaligh yang menyampaikan dakwah khususnya secara lisan agar pesan-pesan dakwah tersebut sampai dan dapat dipahami oleh khalayak.

Evie Effendi dalam dakwahnya, menggunakan bentuk dakwah tabligh, sehingga dalam pelaksanaannya perlu menggunakan retorika yang baik agar pesan dakwah dapat sampai kepada khalayak dan diaplikasikan dalam kehidupan khalayak.

Data primer yang disajikan oleh peneliti adalah video Dakwah Evie Effendi dalam tausiyah nya di Bandung dengan tema Rek Kitu Wae? Yang peneliti dapat dari Youtube. Dalam penyajian data ini akan dijelaskan bagaimana retorika dakwah Evie Effendi di Youtube. Untuk mengungkapkan retorika dakwah Evie Effendi peneliti menganalisis video Youtube dengan judul "Rek Kitu Wae?". Youtube adalah salah satu media bagi umat Muslim untuk melakukan dakwah di Era modern. Youtube berpotensi sebagai media yang diakses hampir semua orang di Indonesia. Tercatat tahun 2015 Indonesia menjadi salah satu Negara pengakses Youtube terbesar se-Asia Pasifik yakni meningkat hingga 130 persen (Nistanto, 2015).

Berdasarkan analisis peneliti terhadap data tersebut, Evie Effendi menerapkan beberapa hal yang menjadi prinsip-prinsip retorika.

\section{Penerapan Lima Hukum Dasar Retorika}

Aristoteles menyebutkan bahwa ada lima hukum dasar dalam penyusunan pidato (The Five Canons of Rhetoric). Dalam dakwah Evie Effendi, ia melaksanakan beberapa hal:

Pertama, inventio (penemuan). Penemuan diinterpretasikan secara luas sebagai sekelompok informasi dan pengetahuan yang dibawa oleh pembicara kedalam situasi berbicara" (Zaini A, 2017). Kajian yang dilakukan oleh Evie Effendi, selalu dihadiri ataupun ditonton oleh banyak orang dari kalangan kaula muda. Terbukti, berdasarkan data primer video yang diambil dari youtube, video tersebut telah ditonton oleh 1 juta lebih penonton. (Rakhmat, 2011: 8).

Kedua, disposition (penyusunan). Berdasarkan analisis terhadap data yang dihimpun dari video ceramah Evie Effendi, penyusunan pesan yang diterapkan 
oleh Evie Effendi hampir sesuai dengan teori Aristoteles. Pada bagian pendahuluan, diisi dengan salam, shalawat, membaca ayat Alqur'an dan hadits yang berkaitan dengan tema, dan pembukaan kalimat yang menggambarkan tema dari ceramah tersebut.

Dari hasil analisis penulis, dalam pendahuluan diatas Evie Effendi menggunakan ayat Alqur'an dan hadits sebagai upaya untuk menumbuhkan kredibiltas. Kemudian disisipi kata singkatan dan humor agar menarik perhatian pendengar. Selanjutnya menjelaskan maksud dan tujuan dari tema yang telah ditentukan.

Setelah pembukaan, Evie Effendi melanjutkan ke bagian pembahasan materi sesuai tema. Ini termasuk pada bagian badan penyusunan pesan. Pembahasan materi dilakukan dengan cerita pengalaman yang dikemas dengan humor yang nantinya akan diambil hikmah dari cerita pengalaman tersebut dan dijelaskan kaitannya dengan ilmu-ilmu agama.

Kemudian, setelah menyampaikan isi ceramahnya, Evie Effendi tidak menutup dengan kesimpulan melainkan dengan membuka sesi Tanya jawab mengenai tema pembahasan maupun dari luar pembahasan. Ini menandakan bahwa penyusunan materi ceramah yang dilakukan Evie Effendi hampir sama dengan teori Aristoteles yang dijelaskan diatas, namun dalam ceramah Evie Effendi tidak menggunakan kesimpulan sebagai penutup ceramah.

Berdasarkan uraian diatas, Evie Effendi sebelum melakukan ceramah, ia telah mengonsep susunan materi, tetapi tidak dengan bahasan yang ia sampaikan. Pembahasannya lebih bersifat spontan sesuai dengan pengetahuan dan pengalamannya karena itu Evie Effendi lebih banyak menyisipkan cerita pengalaman dibungkus dengan humor sehingga pendengar tidak merasa bosan saat mendengarkan ceramahnya.

Ketiga, elucatio (gaya). Tahap ini telah dilakukan oleh Evie Effendi dalam ceramahnya, ia selalu menggunakan bahasa campuran antara bahasa Indonesia dan bahasa daerah Sunda. Hal tersebut dikarenakan tempat Evie Effendi ceramah, bertempat didaerah bandung yang pada dasarnya menggunakan bahasa Sunda, kemudian dikhawatirkan terdapat Jemaah yang berasal dari luar daerah serta kebutuhan untuk disebarkan di media social sehingga Evie Effendi menggunakan bahasa Indonesia.

Kemudian dalam hal diksi, kalimat yang indah dan tepat, Evie Effendi juga menerapkan hal itu dalam ceramahnya. Ia menggunakan gaya bicara sesuai dengan keadaan pendengarnya yang kebanyakan adalah anak muda. Agar pesan dapat diterima dan dipahami oleh pendengar dengan mudah, Evie Effendi menggunakan bahasa sehari-hari, tidak rumit, serta disisipkan humor agar lebih menghibur pendengar.

Keempat, memoria (memori). Analisa penulis terhadap video ceramah Evie Effendi di Youtube, ia tampak mengingat dengan baik tema yang disampaikan 
dalam ceramah tersebut. Hal ini dikarenakan Evie Effendi menjelaskan tema kepada pendengar pada pembukaan ceramahnya, seperti yang diuraikan diatas. Kemudian dalam badan ceramah pun beberapa kali ia menyebutkan tema ceramah "Rek kitu wae?". Tema ceramah tersebut merupakan bahasa sunda yang sering dipakai oleh anak muda sehingga Evie Effendi memakai bahasa tersebut dalam ceramahnya, dan juga kata bahasa sunda tersebut merupakan singkatan dari "Rencanakan Kehidupan, Kuatkan Iman, Tingkatkan Ukhuwah. Wallahu 'alam". Ini menjadi ciri khas Evie Effendi yang sering menggunakan singkatan kata dalam ceramahnya.

Kelima, pronuntiatio (penyampaian). Seperti yang telah dijelaskan mengenai penyampaian Evie Effendi yang selalu menggunakan singkatan kata dalam ceramahnya, juga bermain dengan intonasi, beliau juga memainkan mimik, gesture tubuh agar mendapat perhatian dari khalayak. Dalam memainkan mimik wajah, Evie Effendi kerap memainkan mimik wajah sesuai dengan pesan yang dilontarkan, mimik tersebut digunakan untuk memperkuat makna dari pesan yang dilontarkan.

Kemudian berbicara tentang gestur tubuh, posisi Evie Effendi ketika berceramah yaitu posisi duduk, sehingga beliau tidak terlalu banyak menggunakan gestur tubuh, seperti jalan ke arah kanan, kemudian berjalan ke arah kiri. Ia hanya memainkan gerakan tangan sebagai gestur tubuh untuk mencuri perhatian jemaahnya.

\section{Penerapan Prinsip Retorika Menurut Aristoteles}

Retorika memiliki peran penting dalam kegiatan dakwah, maka dari itu Ustadz Evie Effendi perlu menggunakan retorika yang baik agar pesan dakwahnya dapat diterima dan diaplikasikan oleh jamaahnya (Farhatunisa, 2018).

Menurut Aristoteles ada tiga prinsip retorika yang dapat digunakan untuk mempengaruhi manusia saat melakukan pidato atau ceramah yaitu ethos, pathos dan logos (Rakhmat, 2011: 7). Berikut ini adalah tinjauan retorika persuasive Evie Effendi berdasarkan ethos, pathos, logos:

Pertama, ethos. suatu sikap pembicara untuk meyakinkan pendengar bahwa ia ahli dibidangnya (kredibel) sehingga menjadikan pendengar yakin dan dapat percaya terhadap pembicara (Uchjana, 1993: 352). Evie Effendi sebagai pembicara harus meyakinkan pendengarnya bahwa yang disampaikannya benar, wawasan yang dimilikinya luas sehingga para pendengar tidak ragu untuk mempercayai kebenaran apa yang ia sampaikan.

Kedua, Pathos. gaya penyampaian seorang pembicara yang mampu membangkitkan semangat atau perasaan pendengarnya (Onong Uchjana, 1993: 352). Seorang pembicara dituntut untuk mampu menyentuh perasaan, emosi, harapan, kebencian serta kasih sayang pendengarnya (Rakhmat, 2011: 7).

Pada ceramah Evie Effendi, gaya penyampainnya kebanyakan dikemas 
dengan humor. Tetapi ada pula bagian ceramah yang mengandung prinsip pathos. Dalam ceramahnya, Evie Effendi menyentuh perasaan pendengarnya dengan memposisikan pendengar sebagai korban pembantaian Rohingya, kemudian setelah itu ia memberikan nasihat kepada pendengar agar untuk selalu bersyukur terhadap kenikmatan berbangsa dan bernegara di tanah air ini.

Ketiga, logos. suatu prinsip retorika untuk mendekati pendengar melalui rasionalitas pikirannya. Pembicara dituntut untuk meyakinkan pendengar dengan kata-kata yang logis dengan mengajukan bukti (Rahmat, 2011: 7).

Dalam hal ini untuk menjelaskan makna firman Allah, Evie Effendi menggunakan contoh atau analogi agar mudah dipahami oleh jamaahnya. Kemudian selain itu, ia juga menggunakan kata-kata yang logis dan mudah dipahami oleh akal dan pikiran siapapun yang mendengarkannya.

Sama halnya dengan prinsip retorika persuasi yang diungkapkan oleh Jalaludin Rakhmat yaitu Evie Effendi telah menerapkan empat imbaun dari lima teori yang ada, yaitu imbauan rasional, imbauan emosional, imbauan takut, dan imbauan ganjaran.

\section{Aplikasi Retorika dalam Dakwah Evie Effendi}

Kemampuan retorika atau public speaking dalam dakwah sangat dibutuhkan agar pesan-pesan dakwah dapat sampai langsung kepada pendengar, walaupun dakwah dengan metode ceramah sudah dianggap terlalu konvensional tetapi metode ini tidak dapat tergantikan oleh metode lain yang lebih canggih (Abidin, 2013: 123).

Ceramah Evie Effendi telah menerapkan beberapa teori retorika seperti yang telah dijelaskan diatas, selain itu Evie Effendi juga telah merumuskan beberapa hal untuk mempersiapkan dan menyusun pidato.

Pertama, memilih topik dan tujuan. Sesuai dengan analisis penulis, topik yang didapatkan oleh Evie Effendi bersumber dari pengalaman dan pendapat pribadinya. Kemudian dalam merumuskan judul sudah cukup baik yang ditandai oleh sesuai dengan teori yang ada, yaitu: judul harus relevan, provokatif dan singkat. Selanjutnya yaitu menentukan tujuan, dalam ceramah Evie Effendi sudah sesuai dengan tujuan yaitu bersifat informatif, persuasif dan rekreatif.

Kedua, mengembangkan bahasan. Mengembangkan bahasan perlu dilakukan oleh pembicara agar topik yang disampaikan menjadi lebih jelas, dapat mudah dipahami pendengar, dan menambah daya tarik. Ada beberapa uraian yang dijelaskan oleh Jalaludin Rakhmat mengenai keterangan penunjang, yaitu: penjelasan, contoh, analogi, testimoni, ststistik, dan perulangan. Hasil analisis penulis, bahwa dalam ceramah Evie Effendi hanya menerapkan penjelasan dan contoh saja.

Ketiga, cara membuka dan menutup pidato. Bagian paling penting dalam pidato adalah pembukaan dan penutupan. Pada bagian pembukaan, akan menentukan seberapa besar perhatian dan kesan yang baik yang ditimbulkan 
pembicara kepada pendengarnya. Maka dari itu, dalam pembukaan pidato harus baik (Rakhmat, 2011: 53).

Pada bagian pembukaan ceramah Evie Effendi, diisi dengan salam, shalawat, membaca ayat Alqur'an dan hadits yang berkaitan dengan tema, dan pembukaan kalimat yang menggambarkan tema dari ceramah tersebut.

Selain itu, menurut Aristoteles pendahuluan dapat dijadikan sebagai upaya untuk menarik perhatian khalayak, menumbuhkan kredibilitas, dan menjelaskan tujuan (Uchjana, 2013: 55). Dari hasil analisis penulis, dalam pendahuluan diatas Evie Effendi menggunakan ayat Alqur'an dan hadits sebagai upaya untuk menumbuhkan kredibiltas. Kemudian disisipi kata singkatan dan humor agar menarik perhatian pendengar. Selanjutnya menjelaskan maksud dan tujuan dari tema yang telah ditentukan.

\section{Gaya Retorika Dakwah Evie Effendi di Video Youtube yang Meliputi Gaya Bahasa dan Humor}

\section{Gaya Bahsan}

Gaya bahasa merupakan suatu bentuk kesusastraan yang dapat dipelajari oleh pembicara dalam berpidato (Rakhmat, 2011: 51). Dalam buku Dustur Da'wah Menurut Al Qur'an karya Hasjmy, ada enam gaya bahasa yang digunakan oleh pembicara dalam berdakwah, yaitu: Ta'lim dan Tarbiyah, Tazkir dan Tanbih, Targhib dan Tabsyir, Tarbib dan Inzar, Qashash dan Riwayat, serta Amar dan Nahi.

Hasil analisis penulis, dalam ceramah Evie Effendi terdapat lima gaya Bahasa yang digunakan yaitu Ta'lim dan Tarbiyah, Tazkir dan Tanbih, Targhib dan Tabsyir, Qashash dan Riwayat, serta Amar dan Nahi.

\section{Humor}

Humor diartikan sebagai sesuatu yang bersifat dapat menimbulkan atau menyebabkan pendengarnya (maupun pembawanya) merasa tergelitik perasaannya, lucu, sehingga terdorong untuk tertawa. Terdapat perbedaan antara lelucon dan humor, humor sasarannya adalah diri sendiri atau kelompok si pembawa cerita sendiri. Sedangkan lelucon adalah orang atau kelompok lain dari si pembawa lelucon (Japarudin, 2017: 15). Humor merupakan salah satu metode rekreatif dalam berdakwah, karena dengan adanya humor dalam dakwah, pendengar/mad'u menjadi tidak merasa bosan dengan dakwah yang disampaikan. Boleh jadi ada orang yang menangis karena gembira, tetapi jarang sekali orang tertawa karena sedih (Rakhmat, 2011: 126).

Humor menjadi salah satu ciri khas dalam ceramah Evie Effendi, karena setiap ceramahnya mad'u selalu tertawa. Tetapi dari semua teori humor yang ada, hanya beberapa saja yang digunakan Evie Effendi dalam video ceramahnya, sebagai berikut: exaggeration, parodi, burlesque, dan belokan mendadak. 


\section{PENUTUP}

Berdasarkan hasil dan pembahasan yang merajuk pada rumusan masalah penelitian, peneliti dapat menyimpulkan beberapa hal sebagai berikut:

Pertama. Penerapan retorika Evie Effendi yaitu retorika yang bersifat persuasi, agar jemaah tidak hanya memahami apa yang ia sampaikan akan tetapi melaksanakan apa yang ia sampaikan. Ditinjau dari penerapan lima hukum retorika menurut Aristoteles, Evie Effendi menerapkan kelima hukum tersebut. Selain itu ia juga menerapkan konsep ethos, pathos, dan logos. Tiga konsep tersebut ia terapkan pada pesan-pesan yang disampaikan agar pesan tersebut dapat diterima oleh akal dan pikiran serta menyentuh hati jemaahnya. Jika ditinjau dari konsep imbauan untuk mempengaruhi orang menurut Jalaludin Rakhmat, ia juga menerapkan kelima imbauan yaitu imbauan rasional, emosional, takut, ganjaran, dan motivasional.

Selain itu juga, Evie Effendi menerapkan rumus Jalaludin Rakhmat dalam mempersiapkan dan menyusun pidato dengan memilih topik dan tujuan berdasarkan sumber dari pengalamannya sendiri dan merumuskan judul dengan relevan, provokatif dan singkat. Tujuan dari ceramahnya yaitu bersifat informatif, persuasif dan rekreatif. Kemudian, dalam mengembangkan bahasan ceramahnya, Evie Effendi menggunakan penjelasan, contoh dan perulangan. Selanjutnya, dalam membuka ceramahnya sesuai dengan teori menurut Aristoteles yaitu dengan menarik perhatian pendengar dan menumbuhkan kredibilitas.

Kedua. Gaya retorika dalam dakwah Evie Effendi di video Youtube yang meliputi gaya bahasa dan humor adalah sebagai berikut: Gaya bahasa yang digunakan Evie Effendi dalam dakwahnya ini yaitu menggunakan Ta'lim dan Tarbiyah, Tazkir dan Tanbih, Targhib dan Tabsyir, Tarbib dan Inzar, Qashash dan Riwayat, serta Amar dan Nahi. Kemudian, humor yang digunakan adalah humor Exaggeration, Parodi, Barlesque, dan Belokan mendadak.

\section{DAFTAR PUSTAKA}

\section{Buku}

Bungin M.B. 2008. Metode Penelitian Kualitatif Komunikasi, Ekonomi dan Kebijakan Publik Serta Ilmu-Imu Sosial Lainnya. Jakarta: Kencana.

Bungin M. B. 2011. Penelitian Kualitatif. Jakarta: Kencana

Effendy, Onong Uchjana. 2013. Ilmu Komunikasi: Teori dan Praktek. Bandung:

Remaja Rosda Karya.

Effendy, Uchjana. 1993. Ilmu, Teori, dan Filsafat Komunikasi. Bandung: Citra Aditya Bakti.

Furchan, Arief. 1992. Pengantar Metode Penelitian Kualitatif Suatu Pendekatan Fenomenologis Terhadap Ilmu-Ilmu Sosial. Surabaya: Usaha Nasional. 
R.R.Rahman, A. Mukhlis, \& A.Aripudin

Hasjmy, Ali. 1974. Dustur Da'wah Menurut Al Qur'an. Jakarta: Bulan Bintang. Jaswadi, Ahmad. 2014. Retorika. Surabaya: CV Cahaya Intan XII.

Lubis, Basrah. 1991. Metode dan Retorika Dakwah. Jakarta: CV Tursnia Parwiyuliati, Wiwit. 2017. Respon Jamaah Masjid Abu Bakar Ash-Shidiq Terhadap Gaya Busana Ustadz. Evie Effendie Dalam Berdakwah. Skripsi S1, Fakultas Dakwah dan Komunikasi, Komunikasi dan Penyiaran Islam, Universitas Islam Negeri Bandung.

Rakhmat, J. 2011. Retorika Modern Pendekatan Praktis. Bandung: PT Remaja Rosda Karya

Rakhmat, J. 2013. Psikologi Komunikasi. Bandung: PT Remaja Rosda Karya.

Ridwan, A. 2013. Filsafat Komunikasi. Bandung: Pustaka Setia.

\section{Internet}

Amnestika, Arnita, 2014. Era Komunikasi Tanpa Batas, diakses 20 Juli 2018, dari http:/ / arnitaamnestika.blogspot.com/2014/03/era-komunikasi-tanpa-batasmengintip.html? $m=1$

Fatturahman, Muhammad Nurdin. 2017. Biografi Ustadz Evie Effendi-Ustadz Gaul Bandung, diakses 11 Juli 2018, dari https://biografi-tokohternama.blogspot.com/2017/08/ biografi-ustadz-evie-effendi-ust-gaulbandung.html? $m=1$

Gandapura, Baban, 2017. Jalan Kelam Ustaz 'Gapleh’ Evie: Kisah Penjara, Ibu dan Hijrah, diakses 11 juli 2018, dari https://m.detik.com/news/jawabarat/3605295/jalan-kelam-ustaz-gapleb-eviekisah-penjara-ibu-dan-bijrah

Syarif Hidayatullah, Moch, 2015. Fenomena Da'i Selebriti Sebagai solusi atau Problem Dawah, diakses 8 Juli 2018, dari https://cordofa.org/fenomena-daiselebriti-sebagai-solusi-atau-problem-dakwah/.

\section{Jurnal}

Japarudin. 2017. Humor Dalam Aktivitas Tabligh. Syi'ar Vol. 7 No. 2 Agustus 201 Zaini, A. 2017. Retorika Dakwah Mamah Dedeh dalam Acara "Mamah dan Aa Beraksi" di Indosiar. Dalam Ilmu dakwah: Academic Journal 1 for Homiletic Studies 11(2). 